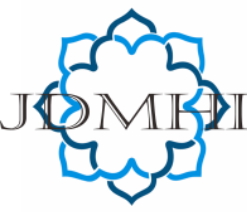

email: jdmhi@walisongo.ac.id

Journal of Digital Marketing and Halal Industry

ISSN: 2716-4810 (print) ISSN: 2716-4802 (online)

\title{
Effect Analysis of Trust, Ease, Information Quality, Halal Product on Online Purchase Decision of 2016 2018 Batch Students of Islamic Economics Study Program in UIN Walisongo at Shopee Marketplace
}

\author{
Hariyanti Rohmah', Zuhdan Ady Fataron ${ }^{2}$ \\ 1,2 Faculty of Islamic Economics and Business, Islamic State University of Walisongo Semarang, Indonesia
}

\section{A R T I C L E I N F O}

Article history:

Received 07 Desember 2019

Received in revised form 14 Januari 2020

Accepted 14 Januari 2020

Keywords:

Trust, Ease, Information Quality, Halal

Product, Purchase Decision

\begin{abstract}
A B S T R A C T
Shopee is an online shop platform that has many users. It cannot be separated from the trust built by the marketplace. Trust, ease, and quality of information become important aspects for marketplaces to attract customer interest. Halal products are special requirements given to customers who are Muslim, in order to avoid things that are prohibited by syara 'against purchasing decisions in the marketplace. To see the effect, a research was conducted on students as the biggest onlineshop actors with variables of trust, ease, quality of information and halal products as independent variables on purchasing decisions as dependent variable. The results showed that the variables of trust, ease, quality of information and halal products had a positive and significant effect on purchasing decisions in shopee marketplace.
\end{abstract}

\begin{abstract}
A B S T R A K
Shopee adalah salah satu platform online shop yang mempunyai banyak pengguna. Hal ini tidak terlepas dari adanya kepercayaan yang dibangun oleh marketplace tersebut. Kepercayaan, kemudahan, dan kualitas informasi menjadi aspek penting bagi para marketplace untuk menarik minat pelanggan. Produk halal adalah syarat khusus yang diberikan untuk pelanggan yang beragama muslim, agar terhindar dari hal-hal yang dilarang oleh syara' terhadap keputusan pembelian dalam marketplace tersebut. Untuk melihat pengaruhnya, maka dilakukan penelitian pada mahasiswa sebagai pelaku terbesar onlineshop dengan variabel kepercayaan, kemudahan, kualitas informasi dan produk halal sebagai variabel bebasnya terhadap keputusan pembelian sebagai variabel terikatnya. Hasil penelitian menunjukkan bahwa variabel kepercayaan, kemudahan, kualitas informasi dan produk halal berpengaruh positif dan signifikan terhadap keputusan pembelian pada marketplace shopee.
\end{abstract}

* Corresponding author. email: zuhdan_ady_fataron@walisongo.ac.id http://dx.doi.org/10.21580/jdmhi.2019.1.1.4772 


\section{Introduction}

The development of a very large and more modern era in Indonesia encourage various kinds of changes both directly and indirectly, such as trading system. Trading or purchase and selling is a part of business work. And most of the goals are to obtain large profits. In this modern era, the rapid development of technology has resulted in changes in personal communication. They have also reformatted the development of organization, production and marketing of goods and services, especially in the advancement of internet technology that has become easy and fast whenever and wherever they are. Internet functions are increasing from day to day in the purchase of goods and services throughout the world.

Tabel 1.

\begin{tabular}{cl}
\hline $\begin{array}{l}\text { Commercial content } \\
\text { visited }\end{array}$ & $\begin{array}{l}\text { Number of visitors } \\
\text { (In million) }\end{array}$ \\
\hline Onlineshop & 82.2 \\
Facebook & 71.6
\end{tabular}

Tabel. 2

\begin{tabular}{lccc}
\hline No & Marketplace & Year & Visitors \\
\hline 1 & Lazada & 2012 & 117,6 juta \\
2 & Tokopedia & 2009 & 117,3 juta \\
3 & Bukalapak & 2011 & 93,6 juta \\
4 & Blibli & 2011 & 45,9 juta \\
5 & Shopee & 2015 & 34,5 juta \\
6 & JD IDE & 2015 & 13,2 juta \\
7 & Bhineka & 1999 & 7,4 juta \\
8 & Elevania & 2014 & 6,3 juta \\
9 & Zalora & 2012 & 5,2 juta \\
10 & Mataharimall & 2015 & 4 juta \\
\hline
\end{tabular}

Sumber: www.iprice2018.com

Based on the above table, it can be known in which the youngest marketplace consists of 3 platforms, they are Shopee, JD ID and Mataharimall. On three of the marketplaces,
Shopee is listed as a young marketplace with a fantastic number of visitors. The marketplace becomes excellent for customers, because it offers low prices and profitable promos 
ranging from free shipping untill postage discounts with very profitable percentages..

But, not do all activities smoothly run including this online buy and sell activity. There are still a lot of problems experienced by users of these services such as reduced trust, because the goods purchased do not match with those ordered and eases that are not fully understood by users and availability of information that has not been conveyed properly. Therefore, this research will explain the effectof trust, ease, information quality and halal products on bpurchasing decisions in Shopee marketplace.

Many previous research have analyze about the trust, ease and quality of information on online purchasing decisions, such as research conducted by (Hardiawan, 2013) who examined marketplace, tokobagus.com, or research conducted by (Pudjihardjo \& Wijaya, 2015) who examined using Shapeharve social media. In this research, the marketplace which researched was Shopee and what distinguished this research from previous research was the presence of halal product variable as a measurement of Islamic economic.

\section{Literature Review}

\section{Buy and Sell}

According to (Dr. Mardani, 2015), buy and sell were one of the transaction activities that occur between seller and buyer on condition that both are voluntary, so that both are mutually beneficial without any side feeling disadvantage.

In order to buy and sell can legally be done according to Islamic law and give the right influence, several conditions must firstly be realized. There are things related to the seller and also the buyer, and There are things related to the object being traded. Buy and sell will be valid, if both were completed. According to Hanafiyah scholars, the pillars of sale and buy are consent and qabul. While according to the jumhur, there are four pillars, they ba'i waal musytari (sellers and buyers), tsaman wa mabi' (prices and goods), and also shighat (ijab and qabul).

According to jumhur ulama, there are four pillars of buy and sell, they are:

1. The person which makes the contract (seller and buyer)

2. Sighat (lafadz of ijab and qabul)

3. There are items to be bought

4. There is a replacement exchange value of goods

\section{E-Commerce}

According to (Asnawi, 2004), progress of technology which is more modern has an impact on global changes, especially in the aspects of business and market activities. This progress was what creates the birth of another transaction method known as e-commerce (electronic commerce). E-commerce is the use of electronic device and technology to conduct trade, including business-to-business and business-to-consumer interactions. Basically, e-commerce includes business activities involving consumers, manufactures, intermediary traders using a computer network, that is the internet.

According to (Hasanuddin Rahman Daeng Naja, 2016), E-commerce is a way to conduct economic activities using the internet as a range of very global applications without time limit and anyone can carry out economic and other activities. Outline, e-commerce is 
currently applied to carry out economic activities.

a. business-to-business is online business communication among business people or it can told with electronic transactions among companies (in the case of business people) and in a large product capacity or volume. The scope of business-to-business in e-commerce activities can be intended to support activities of the business people by themselves.

b. business-to-consumer on this stage is done by way of approach with the consumer by store mechanism (electronic shopping mall). The purpose of electronic shopping mall is an online buy and sell promotion by utilizing a website to peddle products and services.

c. consumer-to-consumer is an electronic business transaction that is more specific in nature, because the transaction is carried out by consumer to consumer who make transactions.

Methode of online payments in e-commerce implementation is by making payments via the internet. A number of aspects that are classified as various business interaction processes very quickly change, when trading is conducted by face to face, it begins to be replaced by online methode. When a person buys an item, there are several steps that must be followed, they are by finding location of the seller, choosing the desired product, asking for the price, making an offer, checking the identity and validity of payment mechanism, and the delivery of the goods between the seller and the buyer.
The changes that occur about buy and sell online require buyers to pay attention to the security of payment methods. Actually, the principle of e-commerce payment is not much different from payments that are at businesses that have store or shanties. The buyer usually will pay for the product or service he buys on the spot which have shanties or store with cash or using credit cards or debit cards. Whereas the principle of e-commerce uses the internet (virtual world) as POS which can be easily accessed through a computer and all digital things and designed with allelectronics, no banknotes, coins, or checks signed with a pen.

\section{Purchasing decision}

According to (Setiadi, 2003), purchasing decision is an integration process that combines knowledge attitude to evaluate two or more alternative behaviors and choose one of them. The purchasing decision process is a process, before a person achieves a purchasing decision, such as planning and deciding on a product to be purchased. Generally, there are five steps in the purchasing decision process, they are

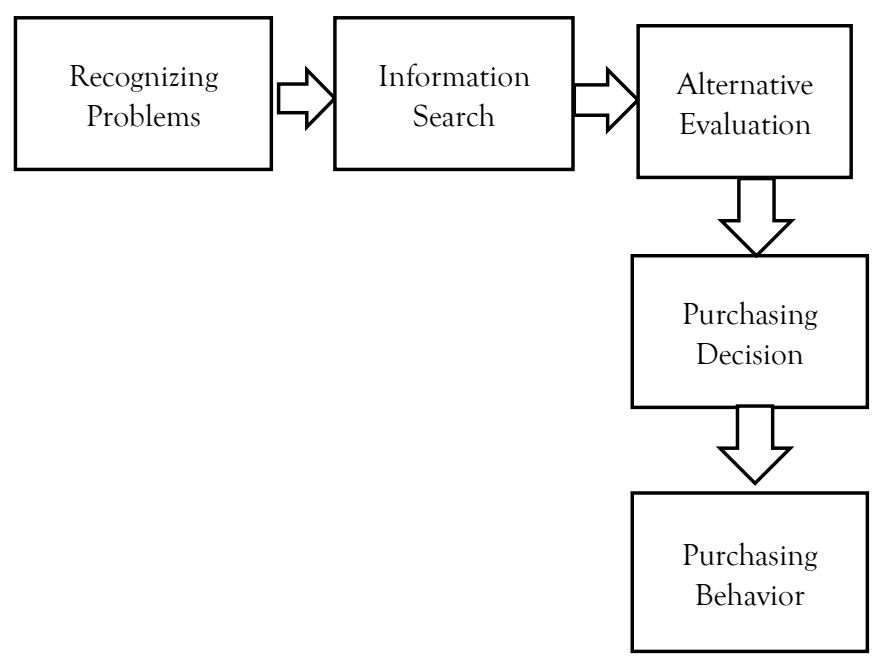


a. Problem reginition recognizes the problem. It purpose the introduction of needs by consumers and requirements that are needed, so that the stimulus appears in which it triggers the emergence of needs (internal) such as hunger and thirst. while In externals, The desire to buy electronic gadget products is through advertisements on the side of the road, so the buyers was aroused to buy it.

b. Information search. At this stage, the consumer deeper delves into further information that is available in environment and stored in memory.

c. Evaluation of alternatives. Consumers begin to enter the stage of purchasing decisions and will evaluate a set of alternative choice assessment using information already obtained.

d. Purchasing decision. Consumers at this stage of purchasing decision will actually buy a product that has been sold.

e. Post-purchase behavior (consumer purchase behavior). Satisfaction obtained by consumers of products that have been purchased affects the behavior of subsequent purchases. When consumers are satisfied with the goods they have purchased, they will most likely repeat it again to buy the product. Conversely, if consumers are dissatisfied, it is likely to spread bad news to others, so that it is important for the company to provide the best possible service to consumers and so that consumers feel satisfied with what is expected to be achieved.

\section{Trust}

According to (Sumarwan, 2003), trust is consumer knowledge about an object, attributes and benefits of an item. Based on this concept, consumer knowledge is closely related to the discussion of attitudes, because consumer knowledge concerns about consumer trust and a product has each of these concepts. There are several benefits of trust, including them:

a. Trust can maintain a cooperative relationship that has been established with trade partners.

b. Trust can be the basis for rejecting short-term choices and more towards long-term benefits by looking after existing partners.

c. Trust can wisely see the high potential risk, because it believes that his partner will not take the opportunity that certainly is detrimental.

Honest behavior is behavior that is followed by an attitude of responsibility for what it does or integrity. Honesty or integrity is like the two sides of a coin, not only does not someone have enough sincerity and honesty but also he requires another driving value, it is integrity. As a result, he is ready to face with a brave, proud, and full of joy, and has never thought of throwing their responsibilities to others.

\section{Ease}

According to (Davis, 1989), ease is how much computer technology is felt to be relatively easy to be understand and to be use. The ease factor is related to how the transaction operations greatly affect a person to make a transaction by providing services and instructions on how it transacts on line, 
starting from ordering, filling in the purchase form to the payment method that will make it easier for consumers to shop online. Ease factors according to (Amijaya, 2010) are time efficiency, ability to conduct transactions, ease of operation and flexible use.

\section{Information Quality}

According to (Sutabri, 2012), a good quality of information is by presenting information that includes its relation to products and existing services on the online shopping. The information should be useful and relevant in predicting the quality and usefulness of product or service. There are 3 things that is be a value of information quality, they are as following:

a. Accuracy, the information must reflect the real situation and must be free from an error.

b. On time, the information that comes to the recipient must not be late. Information that is outdated will no longer have value, because information is the basis for decision making.

c. Relevance, the information has benefits for the wearer.

\section{Halal Product}

According to (Burhan, 2017), halal products are all goods and services that are produced, used or utilized by the community and have halal requirements that are in accordance with Islamic shariah. It is product which does not contain pork or uses alcohol as an ingredient which is intentionally added. As in another definition, halal product is product that meest halal requirements in accordance with Islamic law, they are: a. Halal of subtance in which it means halal from the original law.

b. Halal of methode in which it means that methode is obtained according to Islamic sharia, for example by not stealing.

c. Halal in the process.

d. Halal in its storage that does not contain prohibited goods such as pigs.

e. Halal in its transportation.

f. Halal in its presentation.

\section{Method, Data, and Analysis}

This type of research is a field research with a quantitative approach which is a process of finding knowledge using research data in the form of numbers and danalysis of statistical data, with the purpose to test the hypothesis that had been set. Source of data used in this research consisted of primary and secondary data. Primary data were obtained from distributing questionnaires to a number of respondents who became samples from this research, they were students of Islamic Economics department in Islamic State University of Walisongo Semarang. And secondary data was data obtained from the second source of data needed, for example books, research journals, internet and etc.

The sampling technique used in this research was Non Probability Sampling where not do all members / elements of the population have a same chance to be sampled. With purposive sampling technique, it is determining the sample with consideration of the conditions given for a particular purpose. The considerations used in this research were all students of Islamic Economics department at Faculty of Economics and Islamic Business 
in Islamic State University of Walisongo Semarang

The second technique was Accidental Sampling which was done by searching for objects to be examined by visiting respondents then selecting prospective respondents who were met by chance in accordance with previous considerations.

Research variables used consisted of five variables, they were four independent variables and one dependent variable. The independent variables included trust (X1), ease (X2), information quality (X3) and halal products (X4), while the dependent variable was online purchasing decisions for students in Shopee marketplace (Y). The development of the instrument was carried out through several steps, they were defining operational research variables, compiling indicators of research variables and compiling instruments (research questionnaires) which could be fully explained as following:

Operational Definition and Indicators of Research Variables

\section{Trust}

The measurement of trust variable was adopted from the research (Morgan \& Hunt, 1994) which included:
a. Information truth
b. Image
c. Trust in Quality

\section{Ease}

The measurement of ease variable was adopted from the research (Davis, 1989) which included :
a. Easily obtained
b. Ease of Buying
c. Time efficient

\section{Information Quality}

The measurement of information quality variable was adopted from the research (Gorla, Somers, \& Wong, 2010) which included:
a. On time
b. Accurate
c. Relevant

\section{Halal Product}

The measurement of halal product variable was adopted from the research (Mulyaningrum \& Alghifari, 2018) which included:
a. MUI Halal Certificate
b. BPOM Permit
c. Islamic symbol
d. Store Owner Identity

\section{Purchasing decision}

The measurement of purchasing decision variable was adopted from the research (Mittal, 1989) which included:
a. Make ends meet
b. Repurchase
c. Recommend to others

\section{Data Analisys}

Respondents used in this research were students of Islamic Economics department of Islamic Economics and Business Faculty in ISLAMIC STATE UNIVERSITY OF Walisongo Semarang, the specific was 2016 . 2018 batch of 84 students. Based on data from the respondents obtained and based on age, gender, batch of entry, the number of transactions in 1 year and the most frequently 
purchased goods. The following results were the characteristics of respondents in this research:

In this research, the researcher used a research instrument test, classic assumption test, hypothesis test that included coefficient of determination (R2) and partial test (t), and multiple linear regression analysis using statistical application, SPSS 21.0.

\section{Theoretical Framework and Formulation Of Hypotheses}

\section{Effect of Trust on Purchasing decision}

Consumer trust is consumer knowledge about an object, its attribute and benefit. Based on this concept, consumer knowledge is closely related to the discussion of attitudes, because consumer knowledge concerns about consumer trust in which a product has various attributes and benefits of those attributes.

Research conducted by (Hardiawan, 2013) stated that trust had a positive and significant effect on purchasing decisions, where the research showed that good consumer trust on the seller would add to good purchasing decisions.

$\mathrm{H} 1=$ Trust $(\mathrm{X} 1)$ has a positive and significant effect on Online Purchasing decisions in Shopee Marketplace (Y)

\section{Effect of Ease on Purchasing decision}

Ease of use is be interpreted by the extent to which a person believes that the use of a system will make it free from effort. Based on the result of research conducted, it showed that the system made by shopee starting from a mehtode to get information about shopee, methode to pay and time efficiency in making purchases can provide ease for consumers.
Research conducted by (Pudjihardjo \& Wijaya, 2015) stated that ease in online marketing had an effecton purchasing decisions which showed that the easier it is for consumers to access content in online marketing channels, the more it will add to the purchasing decision. .

$\mathrm{H} 2$ = Ease (X2) has a positive and significant effect on Online Purchasing decisions in Shopee Marketplace (Y)

\section{Effect of Information Quality on Purchasing decisions}

The quality of information is the extent to which information can consistently meet the requirements and expectations of all people who need that information to carry out their processes. Based on the result of research conducted, it showed that the quality of information provided by shopee to consumers was pretty good. It was caused by shopee which always provides the latest information in online media, the information provided by shopee is also right on target and in accordance with what consumers expect, besides that consumers also feel benefits of the information provided.

In a previous research conducted by (Naomi, 2016), she stated that the quality of information had a positive and significant effect on purchasing decisions.

$\mathrm{H} 3$ = Information quality (X3) has a positive and significant effect on Online Purchasing decisions in Shopee Marketplace (Y)

\section{Effect of Halal Product on Purchasing decision}

In a broad definition, products are all goods and services that are produced, used or utilized by the community. the products in 
this research were products that have halal requirements according to Islamic sharia. Research conducted by (Ashari, 2019) showe that product knowledge and halal certification simultaneously have a significant effect on pharmaceutical purchasing decisions.

H4 = Halal Product (X4) has a positive and significant effect on Online Purchasing decisions in Shopee Marketplace (Y)

\section{Result and Discussion}

1. Test Research Instrument

a. Validity Test

Validity test was a measurement used in measuring validity level or research instrument validity.

Table. 3

\begin{tabular}{lcccc}
\hline \multicolumn{1}{c}{ Variables } & Items & R Count & R table & Information \\
\hline Trust Variable (XI) & XI.1 & 0,859 & 0,214 & Valid \\
& X1.2 & 0,849 & 0,214 & Valid \\
& X1.3 & 0,775 & 0,214 & Valid \\
Ease Variable (X2) & X2.1 & 0,795 & 0,214 & Valid \\
& X2.2 & 0,752 & 0,214 & Valid \\
& X2.3 & 0,754 & 0,214 & Valid \\
Information Quality & X3.1 & 0,813 & 0,214 & Valid \\
Variable (X3) & X3.2 & 0,767 & 0,214 & Valid \\
& X3.3 & 0,704 & 0,214 & Valid \\
Halal Product & X4.1 & 0,824 & 0,214 & Valid \\
Variable (X4) & X4.2 & 0,681 & 0,214 & Valid \\
& X4.3 & 0,591 & 0,214 & Valid \\
Purchasing decision & X4.4 & 0,666 & 0,214 & Valid \\
Variable (Y) & Y1.2 & 0,740 & 0,214 & Valid \\
& Y1.3 & 0,761 & 0,214 & Valid \\
& & & 0,214 & Valid \\
\hline
\end{tabular}

b. Realibility Test

Based on table 3 above, it was the processed data about validity, it showed that the 16 question items were valid, because they had an estimated value above $\mathrm{r}$ table, it was 0.214 .
Reliability test is conducted to get answers that were consistent or stable over time, in which a variable was said to be reliable if it had a Cronbach Alpha of more than 0.60. The reliability test result could be seen from the following table:

Table. 4

\begin{tabular}{ccc}
\hline Variable & Cronbach Alpha & Information \\
\hline XI & 0,768 & Reliable \\
X2 & 0,650 & Reliable \\
X3 & 0,637 & Reliable
\end{tabular}




\begin{tabular}{cll}
$\mathrm{X} 4$ & 0,615 & Reliable \\
$\mathrm{Y}$ & 0,617 & Reliable \\
\hline
\end{tabular}

From table 4 above, it could be known that each variable had a Cronbach Alpha of more than 0.60 , so it could be interpreted that all variables $\mathrm{X}$ and $\mathrm{Y}$ were reliable.

\section{Classic assumption test}

\section{a. Multicollinearity Test}

Multicollinearity test purposed to test whether regression model was found by a correlation among independent variables. A good regression model should not occur correlation among independent variables. below this, you could see multicollinearity test result.

Table. 5

Coefficients $^{\mathrm{a}}$

\begin{tabular}{|c|c|c|c|c|c|c|c|}
\hline \multirow[b]{2}{*}{ Model } & \multicolumn{2}{|c|}{$\begin{array}{l}\text { Unstandardized } \\
\text { Coefficients }\end{array}$} & \multirow{2}{*}{$\begin{array}{c}\text { Standardized } \\
\text { Coefficients } \\
\text { Beta } \\
\end{array}$} & \multirow[b]{2}{*}{$\mathrm{t}$} & \multirow{3}{*}{$\frac{\text { Sig. }}{.220}$} & \multicolumn{2}{|c|}{$\begin{array}{l}\text { Collinearity } \\
\text { Statistics }\end{array}$} \\
\hline & $\mathrm{B}$ & Std. Error & & & & Tolerance & VIF \\
\hline 1 (Constant) & 1.168 & .945 & & 1.236 & & & \\
\hline TRUST & .196 & .076 & .254 & 2.574 & .012 & .684 & 1.461 \\
\hline EASE & .179 & .089 & .204 & 2.002 & .049 & .643 & 1.554 \\
\hline $\begin{array}{l}\text { INFORMATION } \\
\text { QUALITY }\end{array}$ & .229 & .085 & .235 & 2.688 & .009 & .869 & 1.150 \\
\hline $\begin{array}{l}\text { HALAL PRODUCT } \\
\text { a. Dependent Variable: }\end{array}$ & $\begin{array}{r}.183 \\
\mathrm{RCHA}\end{array}$ & $\begin{array}{r}.080 \\
\text { ING DECI }\end{array}$ & .238 & 2.293 & .024 & .616 & 1.623 \\
\hline
\end{tabular}

The independent variables were said to not occur multicollinearity if the tolerance value was $\leq 0.10$ and VIF was $\geq 10$. And based on test result, it could be known as following:

1. In Trust Variable (X1), tolerance value was $\leq 0,10(0,684 \leq 0,10)$ and VIF value was $\geq 10(1,461 \geq 10)$, so it could be said that there was no multicollinearity.

2. In Ease Variable (X2), tolerance value was $\leq 0.10(0.643 \leq 0.10)$ and VIF value was $\geq 10(1.554 \geq 10)$, so it could be said that there was no multicollinearity.

3. In Information quality variable (X3), tolerance value was $\leq 0,10(0,869)$
$0,10)$ and VIF value was $\geq 10(1,150$ $\geq 10$ ), so it could be said that there was no multicollinearity.

4. In Halal product variable (X4), tolerance value was $\leq 0,10(0,616 \leq$ $0,10)$ and VIF value was $\geq 10(1,623$ $\geq 10$ ) so it could be said that there was no multicollinearity.

\section{b. Normality Test}

Normality test purposed to test whether in the regression model, confounding or residual variables had a normal distribution. As it was known, $t$ test assumed that the residual value followed normal distribution. 
Table. 6

One-Sample Kolmogorov-Smirnov Test

\begin{tabular}{llr}
\hline & & $\begin{array}{c}\text { Unstandardized } \\
\text { Residual }\end{array}$ \\
\hline N & Mean & 84 \\
Normal Parameters ${ }^{\mathrm{a}, \mathrm{b}}$ & Std. Deviation & .0000000 \\
& Absolute & .78402419 \\
Most Extreme Differences & Positive & .077 \\
& Negative & .077 \\
& & .045 \\
Test Statistic & .077 \\
Asymp. Sig. (2-tailed) & $.200^{\text {c,d }}$ \\
a. Test distribution is Normal. & \\
b. Calculated from data. & \\
c. Lilliefors Significance Correction. & \\
d. This is a lower bound of the true significance. & \\
\hline
\end{tabular}

\section{c. Heteroscedasticity Test}

Based on the table above, it can be known, if the Asymp value. Sig (2-tailed) was $>0.05=$ normal data. In the table above, it showed that Asymp (2-tailed) was 0.200 and could be said that the data was normal.
Heteroscedasticity test purposed to test the possibility of heteroscedasticity symptoms by using glejser test

Tabel 7.

\begin{tabular}{|c|c|c|c|c|c|}
\hline \multicolumn{6}{|c|}{ Coefficients $^{a}$} \\
\hline \multirow[b]{2}{*}{ Model } & \multicolumn{2}{|c|}{$\begin{array}{l}\text { Unstandardized } \\
\text { Coefficients }\end{array}$} & $\begin{array}{l}\text { Standardized } \\
\text { Coefficients }\end{array}$ & \multirow[t]{2}{*}{$\mathrm{t}$} & \multirow[t]{2}{*}{ Sig. } \\
\hline & B & $\begin{array}{l}\text { Std. } \\
\text { Error }\end{array}$ & Beta & & \\
\hline (Constant) & -.137 & .582 & &. .235 & .814 \\
\hline TRUST & -.043 & .047 & -123 & -.923 & .359 \\
\hline EASE & -.019 & .055 & -.047 & -341 & .734 \\
\hline INFORMATION QUALITY & .059 & .052 & .133 & 1.131 & .261 \\
\hline HALAL PRODUCT & .064 & .049 & .183 & 1.310 & .194 \\
\hline a. Dependent Variable: RES2 & & & & & \\
\hline
\end{tabular}

Source : The calculation results of SPSS, 2019

From the table above, it could be seen that variables of trust, ease, information quality and halal product had a value of sig $>0.05$, it meant that there was no heterokedatisitas.

\section{Hypothesis test}

\section{a. Determination Coefficient Test $\left(\mathrm{R}^{2}\right)$}

The coefficient of determination essentially measured how far the model's ability explained variation of dependent variable. The coefficient of determination was between 
zero and one.

Tabel 8. Result of Determination Coefficient Test

\begin{tabular}{|c|c|c|c|c|}
\hline \multicolumn{5}{|c|}{ Model Summary ${ }^{b}$} \\
\hline Model & $\mathrm{R}$ & R Square & $\begin{array}{l}\text { Adjusted R } \\
\text { Square }\end{array}$ & $\begin{array}{l}\text { Std. Error of } \\
\text { the Estimate }\end{array}$ \\
\hline $\begin{array}{l}1 \\
\text { a. Pred } \\
\text { b. Dep }\end{array}$ & $\begin{array}{l}.688^{\mathrm{a}} \\
\text { ors: }(\mathrm{C} \\
\text { dent } \mathrm{V}\end{array}$ & $\begin{array}{l}.474 \\
\text { astant), } \mathrm{X} 4, \\
\text { iable: } \mathrm{Y}\end{array}$ & $\mathrm{X} 1, \mathrm{X} 2$ & .80363 \\
\hline
\end{tabular}

Source : The calculation results of SPSS, 2019

From the result of processing above, it could be seen that the value of $\mathrm{R}$ was $=0.474$, it meant that there was a positive and strong relationship between the variables of trust, ease, quality of information, and halal product. From this table, it was known that the coefficient of determination (R2) was 0.474 which meant that $47.4 \%$ of the dependent variable (Y) could be explained by four independent variables (trust, ease, information quality, and halal product). While the rest $(100 \%-47.4 \%=52.6 \%)$ was explained by other factors which were not examined.

\section{b. Partial Test $(\mathrm{t})$}

This test was used to partially test the significance of variable $\mathrm{X}$ against $\mathrm{Y}$. The sample used was 84 respondents, from the calculation it was obtained t table of 1.664 .

Table 9. Result of Partial Test ( $t$ )

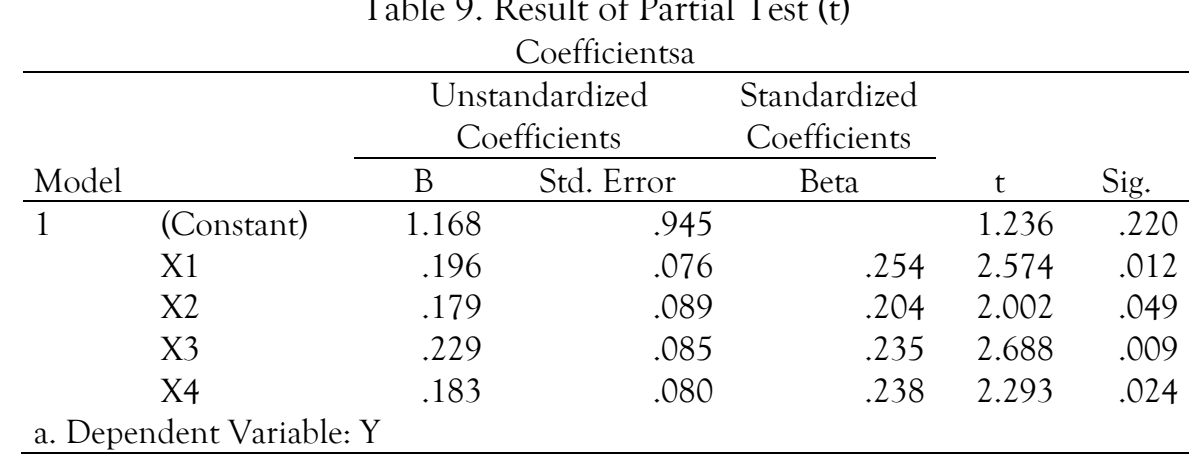

Source : The calculation results of SPSS, 2019

According to table 9, it could be statistically explained by partial test ( $t$ test) of each variable, they were:

- Regression coefficient test of trust variable (X1)

Based on the result table, there was a sig value of 0.012 . The sig value was greater than the probability value of 0.05 or the value of 0.012 $<0.05$, then $\mathrm{Ha}$ was accepted and $\mathrm{HO}$ was rejected. Trust variable had a t-count of 2.574 with $\mathrm{t}$-table $=1.664$. So $\mathrm{t}$ count was $>\mathrm{t}$ table, it could be concluded that trust variable had significant and positive effecton purchasing decision.

- Regression coefficient ease of trust variable (X2)

Based on the result table, there was a sig value of 0.049 . The sig value is smaller than the probability value of 0.05 or the value of 0.049 
was $<0.05$, then Ha was accepted and $\mathrm{HO}$ was rejected. The price variable had a $t$ count of 2.002 with $\mathrm{t}$ table $=1.664$. So $\mathrm{t}$ count was $>\mathrm{t}$ table, it could be concluded that ease variable had significant and positive effecton purchasing decision.

- Regression coefficient test of information quality variable (X3)

Based on the result table, there was a sig value of 0.009 . The sig value was smaller than the probability value of 0.05 or the value of 0.009 was $<0.05$, then Ha was accepted and $\mathrm{HO}$ was rejected. Transaction security variable had $\mathrm{t}$ count which was 2.688 with $\mathrm{t}$ table $=1.664$. So $t$ count was $>t$ table, it could be concluded that information quality variable had significant and positive effecton purchasing decision.

- Regression coefficient test of halal product variable $(\mathrm{X} 4)$
Based on the result table, there was a sig value of 0.024 . The sig value was smaller than the probability value of 0.05 or the value of 0.024 was $<0.05$, then $\mathrm{Ha}$ was accepted and $\mathrm{HO}$ was rejected. The risk perception variable had a $\mathrm{t}$ count that was 2,293 with t table $=1,664$. So t count was $>\mathrm{t}$ table, it could be concluded that halal product variable had significant and positive effecton purchasing decision.

Based on the data above, variables of trust, ease, information quality, and halal product had significant and positive effect on purchasing decision.

4. Multiple Linear Regression Analysis

To find out the effectof independent variables, they were trust, ease, information quality, halal product on dependent variable which was purchasing decision, then multiple linear test was used with the following regression equation:

Table 10. Result of Multiple Linear Regression Analysis

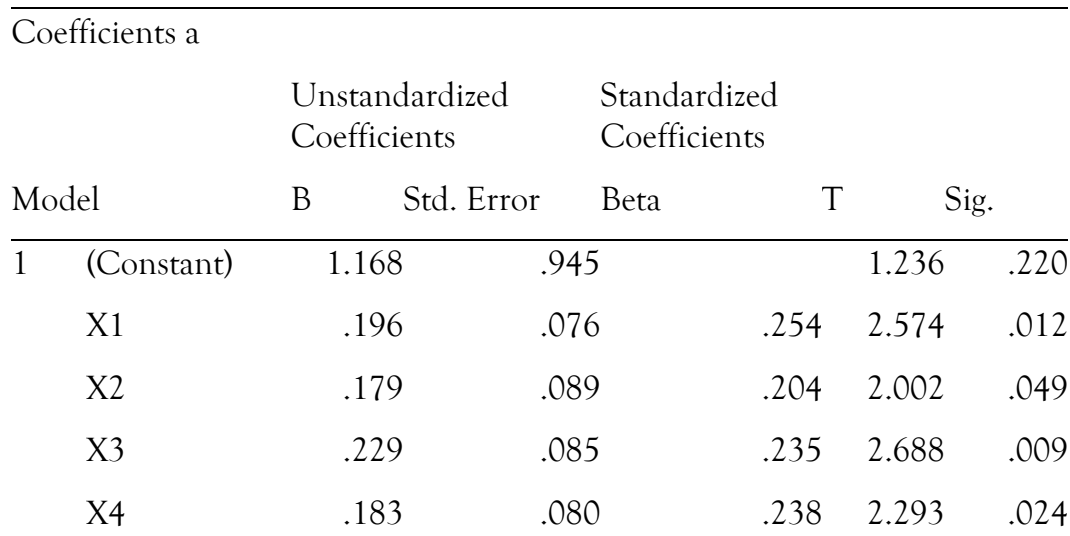

a. Dependent Variable: $\mathrm{Y}$

Source : The calculation results of SPSS, 2019

From table 10 above, it could be seen that $\alpha$ or constant of 1.168 meant that all four variables of trust, ease, information quality, halal product had positive and effecton purchasing decision of 1,168 and the regression coefficient of trust variable (X1) was 0.196 . The coefficient of ease variable 
(X2) was 0.176. The regression coefficient of information quality variable (X3) was 0.229. The regression coefficient pf halal product variable (X4) was 0.183. Therefore, the regression equation model obtained was as following:

$$
\begin{aligned}
& Y=1,168+0,196 X 1+0,179 X 2+0,229 X 3+ \\
& 0,183 X 4+e
\end{aligned}
$$

The results of primary data analysis processed would obtain the following results:

a. Trust variable (X1) had a regression coefficient of 0.196 which meant that on each increase in one unit of trust variable, purchasing decision would also increase by 0.196 or $19.6 \%$.

b. Ease variable (X2) had a regression coefficient of 0.179 which meant that on each increase in one unit ease variable, purchasing decision will also increase by 0.179 or $17.9 \%$.

c. Information quality variable (X3) had a regression coefficient of 0.229 which meant that each increase in information quality variable was one unit, purchasing decision would also increase by 0.229 or $22.9 \%$.

d. Halal product variable (X4) had a regression coefficient of 0.183 which meant that every increase in halal product variable was one unit, purchasing decision would also increase by 0.183 or $18.3 \%$.

\section{DISCUSSION}

The Effect of Trust on Online Purchasing decision in Islamic Economics Department Students of Islamic State University of Walisongo Semarang

Consumer trust is consumer knowledge about an object, its attributes and benefits. Based on this concept, consumer knowledge is closely related to the discussion of attitudes, because consumer knowledge or consumer knowledge concerns consumer trust. A product had various attributes and benefits of those attributes.

Based on research results, it was known that consumer trust in online purchasing decision of Islamic economics students on 2016-2018 batch in shopee marketplace was good. Consumer trust in shopee was formed, because shopee honestly provided information about their products and accordance with reality, so that consumers trust and get a good impression when shopping. The results of this research indicated that trust had positive and significant effect on purchasing decision variable. The results of this research supported previous research conducted by (Hardiawan, 2013) which stated that there were positive effectand significant effecton trust variable on purchasing decision with a regression coefficient of 0.310 . Based on previous research and results of this reserach, it could be concluded if the higher the consumer trust was, the higher the decision was.

The Effect of Ease on Online Purchasing decision in Islamic Economics Department Students of Islamic State University of Walisongo Semarang

Ease of use was interpreted by the extent to which a person believed that use of a system would make it free from effort. Based on the 
results of research conducted, it showed that the system made by shopee starting from method of getting information about shopee, payment method and time efficiency in making purchase could provide ease for consumers.

The results of this research indicated that ease had positive and significant effect on purchasing decision variable. The results of this research also supported previous research conducted by (Pudjihardjo \& Wijaya, 2015) which stated that there was a positive and significant effectof ease variable on purchasing decision with a regression coefficient of 0.292. Based on previous research and the results of this research, it could be concluded that if the higher the ease felt by consumers was, the higher purchasing decision was. conversely, if the system is made difficult for consumers, purchasing decision would be low.

The effect of Information Quality on Online Purchasing decision in Islamic Economics Department of ISLAMIC STATE UNIVERSITY OF Walisongo Semarang

Information quality is the extent to which information can consistently meet requirements and expectations of all people who need the information to carry out their processes. Based on the results of research conducted, it showed that quality of information provided by shopee to consumers was pretty good. This was caused by shopee always provided the latest information in online media and the information provided by shopee was also right on target and in accordance with what consumers expected, moreover consumers also felt benefits of the information provided.

The results of this reseacrh indicated that information quality had positive and significant effect on purchasing decision variable. The results of this research supported previous research conducted by (Naomi, 2016) which stated that there was a positive and significant effecton information quality variable on purchasing decision with a regression coefficient of 0.245 . Based on previous research and the results of this research, it could be concluded, if the information provided had high quality, purchasing decision also was higher. Whereas, if information quality was low, purchasing decision also would be low.

The Effect of Halal Product on Online Purchasing decision in Islamic Economics Department Students of ISLAMIC STATE UNIVERSITY OF Walisongo Semarang

In a broad definition, products are all goods and services that are produced, used or utilized by a community. Halal product must have halal requirements according to Islamic sharia.

The results of this research indicated that halal product had a positive and significant effect on purchasing decision variable. The results obtained from (Ashari, 2019) also showed that product knowledge and halal certification simultaneously had a significant influence on pharmaceutical purchasing decision in which proportion of product knowledge (XI) and halal certification (X2) on purchasing decision (Y) was 0.542 or $54.2 \%$. While for partial test of product knowledge and halal certification on purchasing decisions for pharmaceutical products, it was known that product knowledge (XI) had a positive and significant effect. And the 
second variable, halal certification (X2), also had a positive and significant effect on purchasing decision.

\section{Conclusion, Sugestion \& Research Limitation}

\section{Conclusion}

From the test results conducted in this research, the following conclusions could be drawn:

a. Based on the result of hypothesis test, it could be concluded that trust variable had an effect of $19.6 \%$ (0.196) on purchasing decision, trust also had a significant effect with the $t$ value of (2.574)> $t$ table (1.664).

b. Based on the result of hypothesis test conducted, it could be concluded that ease variable had an effect of $17.9 \% \quad(0.179)$ on purchasing decision, the ease also had a significant effect with $t$ value of $(2,002)>t$ table $(1,664)$.

c. Based on the result of hypothesis test, it could be concluded that information quality variable had an effect of $22.5 \% \quad(0.225)$ on purchasing decision, the quality of information also had a significant effect with $t$ value of $(2,688)>t$ table (1,664).

d. Based on the result of hypothesis test, it could be concluded that expectation variable at the price had an effect of $18.3 \% \quad(0.183)$ on purchasing decision, the expectation on the price also had a significant effect with $t$ value of $(2,293)>t$ table $(1,664)$.

\section{Suggestion}

a. Shopee should maintain the variables of trust, ease, information quality and halal product. Because all of these variables had positive and significant effect on purchasing decision.

b. Shopee should maintain information quality variable, because it had the most dominant effect on purchasing decision. By continuing to provide information that was up to date, relevant and on time, it provided the ease in finding information to consumers.

c. The next researcher could develop this research by using other methods of assessing trust, ease, information quality, halal product and purchas decision, for example by conducting in-depth interviews with respondents, so that the information obtained could be more varied than the questionnaire for which the answers were available.

\section{Research Limitations}

In this research, the variables analyzed had effect on purchasing decision, they are only trust, ease, information quality and halal product. This was caused by the time of research which was limited, so there were still variables that effected purchas decisions and were not included in this research.

Although this research only took four variables, these variables could represent other variables that effected purchasing decision in shopee. But they were not included in this research, the four variables showed a significant effect on purchasing 
decision both simultaneously and partially.

\section{References}

Amijaya, G. R. (2010). Pengaruh Persepsi Teknologi Informasi, Kemudahan, Resiko, dan Fitur Layanan Terhadap Minat Ulang Nasabah Bank Dalam Menggunakan Internet Bangking (Studi Pada Nasabah Bank BCA). Skripsi.

APJII. (2017). Infografis Penetrasi \& Perilaku Pengguna Internet Indonesia. In Teknopreuner.

Ashari, M. (2019). Oleh Mela Ashari (UIN Sunan Ampel). Retrieved from http://digilib.uinsby.ac.id/29232/

Asnawi, H. F. (2004). Transaksi Bisnis Ecommerce Perspektif Islam (Cetakan 1). Yogyakarta: Magistra Insania Press.

Burhan, A. (2017). Strategi Penyaluran Produk Halal Bagi Peserta Diklat Pembina Produk Halal. Jakarta.

Davis, F. D. (1989). Perceived usefulness, perceived ease of use, and user acceptance of information technology. MIS Quarterly: Management Information Systems, 13(3), 319-339. https://doi.org/10.2307/249008

Dr. Mardani. (2015). Hukum Sistem Ekonomi Islam. Jakarta: Rajawali Perss.

Gorla, N., Somers, T. M., \& Wong, B. (2010). Organizational impact of system quality, information quality, and service quality. Journal of Strategic Information Systems.

https://doi.org/10.1016/j.jsis.2010.05.
001

Hardiawan, A. C. (2013). Pengaruh Kepercayaan,Kemudahan, dan Kualitas Informasi Terhadap Keputusan Pembelian Secara Online. Administrasi Bisnis.

Hasanuddin Rahman Daeng Naja. (2016). HOW TO DESIGN SHARIA CONTRACT. Bandung: PT. Citra Aditya Bakti.

Iprice. (2018). Peta E-Commerce Indonesia.

Mittal, B. (1989). Measuring Purchasedecision involvement. Psychology $\mathscr{E}$ Marketing.

https://doi.org/10.1002/mar.4220060 206

Morgan, R. M., \& Hunt, S. D. (1994). The Commitment-Trust Theory of Relationship Marketing. Journal of Marketing. https://doi.org/10.2307/1252308

Mulyaningrum, M., \& Alghifari, E. S. (2018). Perilaku Masyarakat Sunda Muslim Dalam Mengonsumsi Produk Halal Di Kota Bandung. Jurnal Riset Bisnis Dan Manajemen, $\quad 11(1), \quad 34$ https://doi.org/10.23969/jrbm.v11i1.8 70

Naomi, P. E. (2016). Pengaruh Kepercayaan, Kemudahan,Kualitas Informasi dan Harga Terhadap Keputusan Pembelian Pembelian Konsumen Dalam Memilih Berbelanja Secara Online. Segmen Manajemen.

Pudjihardjo, M. C., \& Wijaya, H. (2015). Analisa Pengaruh Kepercayaan, Kemudahan, Kualitas Informasi, Dan Tampilan Produk Terhadap Keputusan 
Pembelian Melalui Pemasaran Di Media Sosial (Studi Pada Pengguna Media Sosial Di Shapeharve). Jurnal Hospitality Dan Manajemen Jasa.

Setiadi, N. (2003). PERILAKU KONSUMEN : Perspektif Kontenporer pada Motif, Tujuan, dan Keininan Konsumen. In prenadamedia group, Jakarta.
Sumarwan, U. (2003). Perilaku Konsumen: Teori dan penerapannya dalam Pemasaran. Ghalia Indonesia, Jakarta.

Sutabri, T. (2012). Analisis Sistem Informasi. In Analisa Sistem Informasi. 
Journal of Digital Marketing And Halal Industry

Vol. I, No. I (2019) 1-18

http://journal.walisongo.ac.id/index.php/JDMHI/index http://dx.doi.org/10.21580/jdmhi.2019.1.1.4772 